\title{
UOT 16
}

\section{EHTIMAL NOZORIYYYSİ İLO QEYRİ-SəLISS MONTIQQIN ELMİ-FəLSəFİ MÜQAYISəSI Və BəDII YARADICILIQDA IFADӘ KONSEPSIYYASI}

\author{
Olişirin Şükürov (Azərbaycan) \\ Riyaziyyat üzrə fəlsəfə doktoru, fəxri professor, \\ DİM, Ali təhsil üzrə sektorun müdiri \\ E-mail: ali_shirin@mail.ru
}

Xülasə. Məqalədə Qeyri-səlis məntiq nəzəriyyəsi və Ehtimal nəzəriyyəsinin təbiət elmləri olaraq fəlsəfəsinə nəzər yetirilir, bu nəzəriyyələrin fərqli tərəfləri ilə yanaşı, oxşar cəhətləri də elmifəlsəfi düşüncə bucağından araşdırılır. Hər iki nəzəriyyənin fəlsəfəsindən intellektual təmayüllü bədii yaradıcılıq nümunələrinin yaradılması zamanı əsas vasitə-körpü olaraq istifadə texnikası ilə bağlı konsepsiya təqdim olunur.

Məqsəd. Hər iki elmi nəzəriyyənin fəlsəfəsinin tədqiqi və ədəbiyyat kontekstində öyrənilməsi.

Metodologiya. Hər iki nəzəriyyəyə elmi-fəlsəfi düşüncə sistemindən yanaşma.

Elmi yenilik. Hər iki nəzəriyyənin elmi-fəlsəfi baxımdan müqayisəli təhlili və intellektual bədii mətnlərin yaradılması üçün təqdim olunan modeldə bu nəzəriyyələrin fəlsəfəsindən istifadənin əsaslandirilmasi.

Açar sözlər. Qeyri-səlis məntiq, çoxluq, universal, stoxastik eksperiment, ehtimal, elementar hadisə, təsadüfi hadisə, fəza, suprematizm.

\section{SCIENTIFIC-PHILOSOPHICAL COMPARISON BETWEEN THE PROBABLE THEORY AND FURRY LOGIC AND CONCEPTION OF APPLYING IN WORK OF ART Alishirin Shukurov}

\begin{abstract}
The article considers philosophy of Furry logic theory and Probability theory as natural sciences, side by side with differing features of these theories, their similar aspects are also studied from the philosophical point of view. Using mechanism of intellectual foundation of philosophy of both theories as a mean - bridge at creating the pieces of art works and related to it conception are suggested.

Purpose: study of philosophy of two scientific theories and examining it in the literary context.

Methodology: approach to both these theories from the point of view of philosophicalscientific system.

Scientific novelty: arithmetic analysis of both theories from scientific-philosophical point of view and grounding the use of philosophy of these theories in proposed model for creation of intellectual textes of art.

Keywords: Furry logic, multitude, inversional, stochastic experiment, exent, space, suprematism.

\section{НАУЧНО-ФИЛОСОФСКОЕ СРАВНЕНИЕ НЕЧЕТКОЙ ЛОГИКИ С ТЕОРИЕЙ ВЕРОЯТНОСТЕЙ И КОНЦЕПЦИЕЙ ВЫРАЖЕНИЯ В ХУДОЖЕСТВЕННОМ ТВОРЧЕСТВЕ Алиширин Шукуров}

Резюме. В статье рассматриваются, теория нечеткой логики и философия теории вероятности, как естественные науки. Помимо различных аспектов рассматриваются также сходства этих теорий с точки зрения научной и философской мысли. Из философии данных 
теорий представлена концепция использования и создания интеллектуально-ориентированных технологий в произведениях искусства.

Цель: исследование философии данных научных теорий и изучение их в контексте литературы.

Методология: подход к обеим теориям со стороны системы научно-философской мысли.

Научная новизна: сравнительный анализ теорий с научно-философской точки зрения и обоснованное использование философии этих теорий в представленной модели, создание интеллектуально-художественных текстов.

Ключевые слова: нечеткая логика, множество, универсальный, стохастический эксперимент, вероятность, элементарное событие, случайное событие, пространство, супрематизм.

\section{Giriş}

Çox zaman müxtəlif elm sahələrinin inkişafı, onların bir-birinə inteqrasiyası hadisələrə, predmetlərə yeni fəlsəfi baxış formalaşdırır və bunun sayəsində yeni fəlsəfi dünyagörüş, yeni fəlsəfi sistemlər yaranır. Eyni zamanda yaranan yeni fəlsəfi sistemlər də müxtəlif elm sahələrində yeniliyə zəmin yaradır. Bu mənada zaman-zaman elmi sahələrlə fəlsəfi dünyagörüş arasında körpü mövcud olmuş və bu əlaqə həyatın bir çox sahələrinə - elmi, elmi-texnoloji, sosial-mədəni, iqtisadi və s. sahələrin dinamikasına müsbət təsir göstərmişdir.

$\mathrm{Bu}$ baxımdan təbiət elmlərinin də fəlsəfi aspektdən araşdırılması xüsusi əhəmiyyət kəsb edir. A.Şopenhauer yazırdı ki, təbiət elmlərinin bizim yüzillikdə insanlar arasında qazandığ 1 parlaq mövqe və şüurlardakı hakimiyyəti o qədər böyükdür ki, bu elmlərlə sıx əlaqədə olmayan heç bir fəlsəfi sistem əsalı təsir gücü qazana bilməz [4]. Hesab edirik ki, dahi filosofun bu fikri çağdaş dövrümüzdə də müəyyən mənada öz aktuallığını itirməyib.

Hazırkı mövzu bəşəriyyət tarixində, elmi və elmi-texnoloji, sosial və iqtisadi sahələrdə, ümumiyyətlə, bütün düşüncə müstəvisində xüsusi dönüş yaratmış iki nəzəriyyənin müqayisəli şəkildə fəlsəfəsinə nəzər salmaqdan, bu bilik sahələrinin elmi-fəlsəfi prizmadan müqayisəsini apararaq bədii yaradıcılıqda rolundan bəhs edir: Qeyri-səlis məntiq (Qeyri-səlis çoxluqlar nəzəriyyəsi) nəzəriyyəsi və Ehtimal nəzəriyyəzi. Hər iki nəzəriyyəyə aid və bu bilik sahələrinin fəlsəfəsi barədə xeyli sayda elmi və elmi-populyar üslubda yazılmış əsərlər mövcuddur. Elə yaxın vaxtlarda Qeyri-səlis məntiq və süni intellekt barədə dəyərli məqalələrin yer aldığı AMEA-nın Fəlsəfə və Sosiologiya İnstitutunun nəşri olan almanax buna yaxşı nümunələrdən biridir [1].

Elə elmi kəşflər var ki, onlar nəinki elmin və onun tətbiq sahələrinin, həm də bədii-fəlsəfi təfəkkürün predmetinə çevrilir. Məqsədimiz də bu müstəvidə, yəni elmi-fəlsəfi duyum məkanında bədii yaradıcılıq sahəsinə səyahət etmək, elmi-fəlsəfi fikirlərdən bədii ifadə vasitəsi kimi istifadə texnikasına yiyələnməkdir. Bu məqamda Haydeggerin bir fikri yerinə düşür: "Şairlər - poetik düşünən filosoflardır. Doğrudan da, yaradıcı şəxsin ətrafa fəlsəfi baxışı, dünya fəlsəfi sistemlərindən bəhrələnməsi bədii mətn yaratmaq prosesində vacib amillərdir. Hadisələrə fəlsəfi yanaşma təsvir olunan hadisələrə dərin məna çalarları gətirməklə yanaşı, mövzu seçimində də əhəmiyyətli rol oynayır. Bu düşüncə adi görünən, yaradıcı təfəkkür ücün sanki ögey hadisələrə belə, bədii don biçə bilir. Nəticədə, ənənəvi olmayan mövzular yaranır. Və ya bu düşüncə vasitəsilə populyar mövzular da yeni bədii biçimdə ərsəyə gəlir. İstər ənənəvi, istər populyar mövzulara fərqli yanaşma nəticəsində yeni ədəbiyyat hadisələri baş verir. Ciddi yaradıcılığın əsas xüsusuyyəti yenini yaratmaq olduğundan, bu sferada fərqliliyi doğuran elmi-fəlsəfi düşüncənin rolu xüsusi əhəmiyyət kəsb edir. Yəni elm, fəlsəfə və ədəbiyyat birgəliyi intellektual bədii mətnlərin yaranması ilə nəticələnir ki, bu sahə ədəbiyyatın xüsusi qolunu təşkil edir [7].

\section{Ehtimal nəzəriyyəsi}

Məqsədimizdən biri bu iki elm sahəsinin müqayisəli elmi-fəlsəfi təhlilini aparmaq olduğundan, əvvəlcə Ehtimal nəzəriyyəsinin predmetini və fəlsəfəsini nəzərdən keçirməyi məqsədəuyğun sayırıq. 
Ehtimal nəzəriyyəsi stoxastik (təsadüfi) eksperimentlərin (sınaqların) riyazi modelini öyrənən elmdir. Stoxasik sınaq nəticəsi əvvəlcədən birqiymətli təyin olunmayan ( nəticəsi təsadüfi olan) sinaqlardır. Yəni, bu nəzəriyyə stoxastik sınağın nəticəsi ilə bağlı təsadüfi hadisə və proseslərin kəmiyyət xüsusiyyətlərini - riyazi qanunauyğunluğunu öyrənən elm sahəsidir.

Təsadüfi hadisə nədir? Elmi-fəlsəfi düşüncə tarixində təsadüfi hadisəyə müxtəlif münasibətlər mövcud olmuşdur. İlk növbədə, fəlsəfi yanaşmalara qısa nəzər salaq. Bəzi yanaşmalardan aydın olur ki, hadisə, ümumiyyətlə, təsadüfi xarakter daşıya bilməz, çünki hər bir hadisəni doğuran səbəb olduğundan bütün hadisələr qanunauyğun baş verir. Sadəcə, hadisələr arasında səbəb-nəticə əlaqəsi qurula bilmədiyindən, yəni bilməzliyin nəticəsində təsadüfi hadisə anlayışı meydana gəlir. Bir sözlə, təsadüfi hadisə bilməzliyin nəticəsidir. Ogər hər hansı hadisənin başvermə səbəbi bilinsəydi, bu zaman hadisə təsadüfilik kimi xüsusiyyət daşımaz və zəruru hadisə sayılardı. Böyük Azərbaycan filosofu Bəhmənyar yazır ki, heç bir hadisə və predmet insan biliyindən kənarda qalmasaydı, onun üçün heç nə təsadüfi olmazd1, hər şey zəruri olard1. $\mathrm{O}$, bir nümunə göstərir: bir adam yol ilə gedərkən xəzinə tapır. Onun xəzinə tapması təsadüfi sayılır. Amma onu xəzinəyə aparan səbəb olmuşdur. Onu xəzinəyə aparan səbəb olduğu üçün təsadüfi sayılan hadisə (adamın xəzinə tapması), əslində, zərurətdən baş vermişdir.

Deməli, təsadüfi hadisə sırf subyektiv xarakter daşıyır və insan bilməzliyinin nəticəsi olaraq ortaya çıxır. Həyatda nə baş verirsə, qanunauyğun şəkildə baş verir. Təsadüfi hadisə anlayışı təkcə fəlsəfi düşüncəni deyil, elmi təfəkkürü də məşğul edən anlayışlardan biridir. Ehtimal nəzəriyyəsi elə təsadüfi hadisələri öyrənir ki, onlar hər hansı qanunauyğunluqlara tabe olur və bu qanunauyğunluqlar "ehtimal qanunauyğunluqları" adlandırılır. Deməli, təsadüfi hadisələr də hər hansı bir qanunauyğunluğa tabedir. Ehtimal nəzəriyyəsinə görə, təsadüfi hadisə o hadisədir ki, eyni şərtlər hər dəfə ödəndikdə baş verə də bilər, baş verməyə də. Yəqin (zəruri) hadisə isə eyni şərtlər ödəndikdə hər dəfə baş verən hadisədir. Hadisənin ehtimalı bu nəzəriyyənin əsas anlayışlarından biridir, hətta belə demək mümkünsə, bu nəzəriyyənin mahiyyətinin daha dolğun ifadə edən riyazi aparatdır: hadisənin ehtimalı hadisənin başvermə mümkünlüyünün dərəcəsini ifadə edir [5,6].

Ümumiyyətlə, Ehtimal nəzəriyyəsinin bir çox anlayışları və məsələləri fəlsəfi düşüncəni işə salır, maraqlı olduğu qədər də gözlənilməz yozumlar ərsəyə gətirir. Hər bir hadisə ətrafinda fərziyyələr, eyni zamanda nəticələr şəbəkəsi yaradır. Məsələn, hər hansı bir hadisə ilə üzləşən şəxs onu bu hadisəyə düçar edən səbəblər barədə düşünür, nəticəni dəyişə bilən müxtəlif variasiyalar ağlından keçir, müxtəlif ehtimallar qurur.

\section{Qeyri-səlis məntiq}

Bu məntiq illərin sınağından çıxmış Binar məntiqə (“Aristotel məntiqi” də deyilir) alternativ yeni düşüncə şəbəkəsi formalaşdıraraq həyatın bir çox sahələrində, o cümlədən yaradıcı sahələrdə də yeni intellektual təmayüllü əsərlərin meydana gəlməsinə zəmin yaradır. Həmçinin ədəbiyyatda. Nədir "Qeyri-səlis məntiq"?

Binar və ya Aristotel məntiqinə görə, bir mülahizə ya doğrudur, ya da səhvdir. Göründüyü kimi, yalan və doğru arasında aralıq dərəcələr, aralıq vəziyyətlər nəzərə alınmır. Fikrimizi bir qədər genişləndirərək izah məqsədi ilə bu kimi mühakimələr irəli sürə bilərik: bu məntiqə görə, bir mülahizə doğru deyilsə, yalandır, bir şey ağ rəngdə deyilsə, qaradır, insan xoşbəxt deyilsə, bədbəxdir, hər hans1 şəxs dost deyilsə, düşməndir, adama olan hiss sevgi hissi deyilsə, nifrətdir və s. Bu mühakimələrdən sonra bu məntiqin mahiyyəti anlaşılır, yəqin ki.

Lakin uzun müddət düşüncə adamlarını çoxölçülü məntiq düşündürmüş, Aristotel məntiqinin (ikili məntiqin) tarix boyu bir çox sahələrdə səmərə verməsinə baxmayaraq, çatışmazlıqlarını, qüsurlarını anlamışlar. $\mathrm{Bu}$ məntiqə görə, iki əks mülahizə arasında qalan nüanslar nəzərə alınmadı̆̆ından, bu nüansların, belə demək mümkünsə, hüquqları "tanınmamış" olaraq qalırdı.

İlk dəfə Lütfi Zadə tərəfindən 1965-ci ildə irəli sürülən Qeyri-səlis məntiq (Qeyri-səlis çoxluqlar) nəzəriyyəsi elmi şəkildə çoxölçülü məntiq məsələsini həll etmiş oldu. Bu məntiqə görə, mütləq heç nə yoxdur və var olan hər şey dərəcəsi ilə mövcuddur. A $\breve{g}$ və qara rəng, yalan və doğru, sevgi və nifrət, xoşbəxtlik və bədbəxtlik və s. müxtəlif bir-birinə əks mülahizələr arasında sonsuz 
sayda aralıq kateqoriyalar, nüanslar mövcuddur; ağ rəng də dərəcəsi ilə mövcuddur, qara da. Xoşbəxtlik də, bədbəxtlik də, sevinc də, kədər də elə. Yəni, bir daha qeyd edirik, bu məntiqə görə, yaranan nə varsa, yalnız dərəcəsi ilə mövcuddur.

Anlaşılan dildə q1sa elmi-kütləvi izahını da verməyə çalışaq. Binar məntiqə aid məsələlərdə iki qiymət mövcuddur: 0 və 1 . Yəni hər bir mülahizənin doğruluq qiymətini iki məntiqi səviyyə müəyyən edir: doğru - 1 (vahid), yanlış - 0 (sıfır). Qeyri-səlis məntiqə aid məsələlərdə isə qiymət 0 və 1 arasında olan bütün ədədlər ola bilər. Yəni hər hansı bir mülahizənin doğruluq qiyməti bu iki səviyyə - 0 (yanlış) və 1 (doğru) - arasında sonsuz qiymətlər çoxluğu ilə müəyyən edilir. $\mathrm{Bu}$ qiymətlər çoxluğu isə, qeyd olunduğu kimi, varlığın mövcudluq dərəcəsini ifadə edir.

Çoxölçülü məntiqin yaranması elmi və praktiki əhəmiyyəti ilə yanaşı, düşüncə sferasında da inqilab yaratdı. Bu inqilab isə digər elmi-fəlsəfi inqilablar kimi yaradıcı sahələr üçün yeni imkanlar açır. Bu imkanlar hadisələrə fərqli yanaşma tərzi aşılamaqla, istər-istəməz, fərqli bədii əsərlərin doğulması üçün bir baza, sanballı düşüncə şəbəkəsidir. Bu məntiqə bələd olan yaradıcı şəxs dost olmayanı həmişə düşmən hesab etmir. Anlayır ki, sevgi və nifrət arasında çoxlu aralıq mərhələlər, vəziyyətlər var. Bilir ki, ağ və qara rəng arasında sonsuz çalarlar mövcuddur. Dərk edir ki, xoşbəxt olmamaq hələ bədbəxt olmaq deyildir.

Yəni, içində olduğu hadisələri fərqli idrakla qavrayır, hadisələrə fərqli fəlsəfi düşüncə ilə və eyni zamanda tolerant yanaşa bilir. Bu məqamda Stoistlərə məxsus bir tezisi xatırlamadan keçmək istəmədim: "İnsan istəyinə uyğun olaraq hadisələri dəyişə bilməz, amma hadisələrə münasibətini dəyişə bilər və dəyişməlidir" [3]. Fəlsəfəsi dərin olan nəzəriyyələr, elmi kəşflər müəyyən hadisələrə qarşı düşüncə tərzini dəyişir və həyatın müxtəlif sahələrinə tətbiqi baxımından faydalılıq əmsalı da yüksək olur. $\mathrm{Bu}$ məntiqin formaış̧dırdığ 1 fəlsəfi düşüncə, həm də tolerant münasibət yaradıcı sahələrdə informativliklə yanaşı, gözlənilməzlik də yarada bilir ki, bu da əsərin bədii dəyərini, fəlsəfi yükünü artırmaqla, yeni ədəbi-bədii estetikanın da yaranmasına təkan verir.

Qeyri-səlis məntiq bizi öyrədir ki, mövcud olan nə varsa, dərəcəsi ilə mövcuddur. Dərəcəsi ilə mövcuddursa, demək, həm də özündə müəyyən qədər tərsini saxlayır. Tərsini saxlayarsa, demək, mövcud olan nə varsa, müəyyən həddən sonra öz tərsinə də çevrilə bilər: sevgi nifrətə, nifrət sevgiyə, bədbəxtlik xoşbəxtliyə, xoşbəxtlik bədbəxtliyə, sevinc kədərə, kədər sevincə.

\section{Qeyri-səlis məntiq və Ehtimal nəzəriyyəsi: oxşar və fərqli xüsusiyyətlər}

Hesab edirik ki, bu məqamda artıq hər iki bilik sahəsini birlikdə nəzərdən keçirməyin vaxtıdır.

Bəzi elmi mühakimələrdə bu iki nəzəriyyəni bir-birilə səhv salır və yaxud eyniləşdirməyə cəhdlər olur. Bu, kökündən yanlışdır. Artıq yuxarıda hər iki nəzəriyyə barədə verdiyimiz elmi-fəlsəfi məlumatlar bu iki elm sahəsinin bir-birindən fəqləndiyini isbat edir.

Elmi ədəbiyyatlarda daha çox bu iki nəzəriyyənin fərqli elm sahələri olub, heç bir kəsişməsinin olmadığını iddia edirlər. Bu iki nəzəriyyənin tamamilə fərqli elm sahələri olduğunu, onlar arasındakı tutarlı fərqin Zadənin “İmkanlar” nəzəriyyəsi əsasında sübutunu nümunə olaraq göstərmək olar [2]. Lakin bu nəzəriyyəyə qədər istər Ehtimal nəzəriyyəsinin, istərsə də Qeyri-səlis məntiqin predmeti, işlənən riyazi aparat, elmi metodologiya özü sübüt edir ki, bu elm sahələri riyaziyyata əvəzsiz töhfələr bəxş edən fərqli nəzəriyyələrdir. Amma qeyd etmək yerinə düşər ki, bu iki nəzəriyyənin oxşar cəhətləri də vardır. Bu iki elm sahəsinin müqayisəli təhlili, oxşar və fərqli cəhətlərini daha geniş təfsilatlara varmadan aydınlaşdırmaq məqsədilə müəyyən ümumiləşmələr aparaq.

\section{Oxşar xüsusiyyotlor nadon ibarotdir:}

Hadisənin ehtimalı və Qeyr-səlis çoxluq ədədi funksiya olub, həqiqi qiymətlər alan funksiyalardır və hər ikisinin qiymətlər çoxluğu - [0,1] parçasıdır. Bu məqamda bir analogiya da yerinə düşər. Hər iki funksiyanın ədədi qiyməti qiymətlər çoxluğunun uc nöqtələrində bərabərdir. Qeyri-mümkün hadisənin ehtimal funksiyası sıfra, mütləq (zəruri) hadisənin ehtimal funksiyası isə vahidə bərabərdir. Qeyri-səlis çoxluq sıfra bərabərdirsə, klassik çoxluq anlayışı baxımından bu, elementin çoxluğa daxil olmaması, vahidə bərabərdirsə, elementin çoxluğa daxil olması deməkdir.

Hər iki elmi anlayış funksiya olaraq çoxluğun funksiyasıdır. Məlum olduğu kimi, Qeyr-səlis çoxluq universal çoxluğun (universal çoxluq - istənilən təbiətə malik çoxluq bu çoxluğun altçoxluğu 
kimi qəbul edilir) funksiyası kimi, Hadisənin ehtimalı isə elementar hadisələr fəzasının (elementar hadisələr fəzası elə çoxluqdur ki, onun hər bir elementi stoxastik sınağın yalnız bir nəticəsini təyin edir) altçoxluğu - təsadüfi hadisənin funksiyası kimi təyin olunub $[5,6]$.

\section{Forqli xüsusiyyotlor:}

Oxşar xüsusiyyətlər, göründüyü kimi, yalnız bu elm sahələrində istifadə olunan əsas riyazi aparat olan funksiyaların (hadisənin ehtimalı və qeyri-səlis çoxluq) müəyyən oxşarlığından ibarətdir. Amma bu elm sahələrinin öyrəndiyi obyektlərin (predmetlərin) elmi mahiyyəti və fəlsəfəsi tamamilə fərqlidir.

Hər iki funksiya hadisəyə münasibətdə dərəcə (dərəcə - burada mümkünlük dərəcəsi mənasında işlədilir) ölçüsünü müəyyən edir. Bu, doğrudur. Amma fərq nədədir?

Ehtimal nəzəriyyəsinin əsas anlayışı (və necə deyərlər, "nüvə"si sayılan) budur ki, hadisənin ehtimalı hadisənin baş verməsi mümkünlüyünün dərəcəsini ifadə edir.

Qeyri-səlis çoxluq isə hadisənin "necə olması" dərəcəsini qiymətləndirir.

$\mathrm{Bu}$ iki nəzəriyyə arasında əsas fərqi müəyyənləşdirməklə bağlı aydın təsəvvür yaratmaq məqsədilə bir neçə nümunə göstərək.

Nümunə 1: Qutuda $\boldsymbol{n}$ sayda ağ, $\boldsymbol{m}$ sayda qara kürəcik var. Təsadüfi qaydada bir kürəcik çıxarılır. Qutudan ă̆ kürəciyin çıxarılması hadisənin mümkünlük dərəcəsini hadisənin ehtimalı müəyyən edir. Çıxan ağ kürəciyin bəyazlıq dərəcəsini (yəni nə dərəcədə ağdır) isə Qeyri-səlis çoxluq qiymotləndirir.

Nümunə 2: A. adlı şəxsin Bakı şəhərində yaşayan qohumları bu şəxsin həmin şəhərdə yaşayan qohumlarından ibarət bir çoxluq təşkil edir. Bu şəxsin şəhərdə gəzərkən qohumlarından birinə rast gəlməsi hadisəsinin mümkünlük dərəcəsi bu hadisənin ehtimalı vasitəsilə qiymətləndirilir (Ehtimal nəzəriyyəsi). Amma qeyri-səlis çoxluq isə o şəxsin A.-ya qohumluq dərəcəsini təyin edir: övladıdır, nəvəsidir, əmisidir, əmioğludur və s. (Qeyri-səlis məntiq).

Nümunələrdən də göründüyü kimi, bu elm sahələri hadisələrə tamamilə fərqli elmi prizmadan yanaşır və hər iki elm sahəsinə məxsus qiymətləndirmə aləti mahiyyətcə tamamilə fərqli olub, ayr1ayrı ölçü vahidləri olaraq müəyyən edilmişdir.

Bu iki elm sahəsinin fəlsəfəsi ilə yanaşı, oxşar və fərqli tərəflərinin müqayisəli təhlili həm də intellektual səciyyəli bədii yaradıcılıq nümunələrinin ərsəyə gəlməsi ilə bağlı konsepsiyamızın əsaslandırılmasında da xüsusi əhəmiyyət kəsb edir. Belə ki, bir çox elmi nəzəriyyələrin, elmi anlayışların fəlsəfəsinin oxşar cəhətlərilə yanaşı, onların fərqinin aydınlaşdırılması intellektual bədii mətnlərin yaranması zamanı belə anlayışların dəqiq elmi-fəlsəfi fakt olaraq istifadəsini təmin edir ki, bu da həmin formatda mətnlər üçün çox vacib məsələdir.

\section{Elmi informasiyanın fəlsəfəsinin bədii yaradıcılıqda ifadəsi}

İntellektual səciyyəli bədii mətnlərin yaranması üçün təqdim etdiyimiz model üç komponentdən ibarətdir: elmi informasiya, fəlsəfi düşüncə, bədii təfəkkür $(\boldsymbol{E} \dot{I}-\boldsymbol{F D}-\boldsymbol{B T})$. Bu konsepsiyaya uyğun hazırladığımız Odəbi suprematizm nəzəriyyəsinin [7] əsasını həmin model təşkil edir və elmi informasiyanın fəlsəfi düşüncə vasitəsilə bədii mətnə gətirilməsi texnikası bu modelin köməyilə həyata keçirilir. Bəs bu cür mətnlərin yaranması hansı mərhələlərdən keçir, bu mətnlərin yaranması üçün təqdim etdiyimiz model hansı halda işlək vəziyyətə gəlir? Bu məsələlərlə bağlı fikirlərimizi sistemləşdirməyə çalışaq.

Ümumiyyətlə, bədii mətnlərin ərsəyə gəlməsi, fikrimizcə, əsasən, aşağıda göstərilən iki mərhələdən keçir: 1. Mövzu kimi seçilmiş hadisə; 2. Mövzu üzərində yaradıcı təfəkkürün funksionallığı.

Ovvəlcə təqdim etdiyimiz modelin $(\boldsymbol{E} \dot{\boldsymbol{I}}-\boldsymbol{F D}-\boldsymbol{B T})$ qurulması mexanizmindən başlayaq. Bu məqsədlə yuxarıda qeyd etdiyimiz mərhələlərə nəzər salaq. Hər hansı hadisənin mövzu seçilərək bədii mətnə çevrilməsi üçün, təbii ki, ilk növbədə yaradıcı təfəkkür işə düşür. Həm də əksinə, yaradıc1 təfəkkürün mövzu seçimində də məxsusi rolu vardır. Çünki bu iki mərhələ arasında həmişə korrelyasiya - asılılıq və əlaqə mövcuddur. İkinci mərhələdə bədii mətnin, bir növ, taleyi həll olunur. Bu mərhələdə hadisəyə təkcə adi (hiss, duyğu ilə yüklü) yaradıcı təfəkkürlə yanaşılan zaman 
müəyyən bədii mətnlər yaranır ki, onlar intellektual xarakter daşımır. İntellektual təmayüllü bədii mətn yazılan zaman təfəkkürü duyğudan ayırmaq (ya da qismən ayırmaq) lazımdır. Yaradıcı təfəkkür elmi faktlarla zəngin olduğu - rasional xarakter daşıdığ 1 halda, intellektual mətnin yaranmasını şərtləndirir. Yəni əsas məsələ qələmə alınan mövzunun elmi-bədii laboratoriyadan keçib bədii mətnə çevrilməsidir. Məhz yaradıcı təfəkkürün rasional xarakterli funksionallığı bədii mətnlərin yaranması prosesində elmi informasiya $(\boldsymbol{E} \dot{\boldsymbol{I}})$, fəlsəfi düşüncə $(\boldsymbol{F D})$ və bədii təfəkkürdən $(\boldsymbol{B T})$ ibarət komponentləri bir sistem halına gətirərək idarə edə bilər. İntellektual bədii mətnin yaranması üçün təqdim etdiyimiz model elə bu üç komponentin bir sistem halında idarə olunmasıdır: $\boldsymbol{E} \dot{\boldsymbol{I}}-\boldsymbol{F D}-\boldsymbol{B T}$.

Qeyri-səlis məntiq adəbiyyatda. Elmi faktlar fəlsəfi düşüncəyə yol açmaqla ədəbiyyatdan, bədii mətnlərdən də yan keçmir. Həm də bu məqsədlə yuxarıda nəzəriyyənin elmi-kütləvi izahına və fəlsəfəsinə nəzər saldıq ki, bu nəzəriyyənin intellektual bədii mətnlərlə əlaqəsindən və əhəmiyyətindən bəhs etməyə cəhd edək.

Hər hansı bir elmi nəzəriyyənin, elmi anlayışın mahiyyətini, fəlsəfəsini anladıqda, onun üzərində və ya ondan bədii vasitə olaraq istifadə edilməklə, qurulan bədii mətnin ötürdüyü informasiya anlaşıla bilər. Və yalnız bundan sonra bu mətnlərdən bədii həzz alınması mümkündür. Adətən, belə hallarda həzzi bədii mətnlər üzərində düşünməyi sevən, bədii mətnlərdə informativlik axtaran oxucular yaşaya bilirlər.

Çoxölçülü məntiq düşüncə sistemində əsaslı dəyişikliyə səbəb olan digər sanballı elmi nəzəriyyələr kimi, bədii-fəlsəfi düşüncə, ümumiyyətlə, yaradıcı təfəkkür üçün çoxölçülü imkanlar açır, hadisələrə, predmetlərə olan münasibət sferasını genişləndirməklə, həqiqətən, sərbəst düşüncə meydanını da genişləndirir. Hesab edirik ki, bu məqamda mövzuya adekvat bədii mətn söylədiklərimizi, qismən də olsa, tamamlaya bilər. Və bu nəzəriyyənin düşüncə sistemindəki rolunu və möhtəşəmliyini bədii mətndəki təsvir və ifadələrdə, az da olsa, hiss etmək mümkündür.

\author{
Şair-filosof \\ Şair-poetik düşünan filosofdu - deyir Haydegger. \\ Man da düşünürəm neçə illardi: \\ yaranan no varsa, \\ talabdan doğar, \\ şəkli əks olunar düşüncədə, \\ sonra yavaş-yavaş istzyə dönər. \\ Hoyat var a, asta-asta ölümdü elo, düşünsən dərindən, \\ düşünson dorindan, \\ sevgi-bir az da nifratdi, nifrat - bir az sevgi, \\ sevinc - bir az kadardi, kadar - bir az sevinc, \\ xoşbəxtlik - bir az bədbəxtlikdi, bədbəxtlik - bir az səadət. \\ qalaba - mağlubiyyatdi ham do, \\ mağlubiyyat - qalabo. \\ (Har şey ifratda öz tarsina çevrilar). Ela çevrilar, \\ bir da görarsan, sevinc kadara dönüb, \\ saadat acıya, qalabo mağlubiyyatว, \\ ya da tərsinə, Odur ki, galin şükür edək tale verənə. \\ Var olan-yox olandl, \\ Yox olan - var olan. \\ Ölüm - hoyatın davamı; yoxolma deyil, \\ şüurun məhsulu - bu yerdə, deyəsən, səhv edar şüur. \\ Şair-poetik düşünən filosofdu. \\ Man do \\ düşündüm, düşündüm, düşündüm ...
}




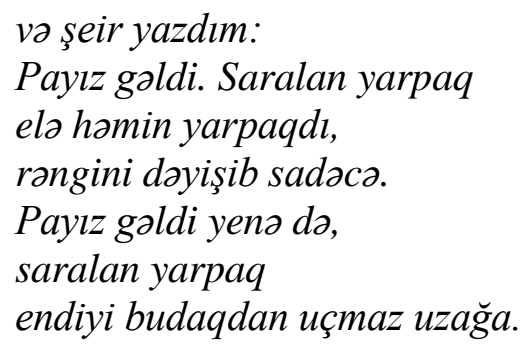

Ehtimal nəzəriyyəsi və ədəbiyyat. Deməli, elmi təfəkkür hadisənin fəlsəfəsinə daha dərindən baş vurmağa imkan yaradır. Lakin elmi anlayışlar, o cümlədən təsadüfi hadisə, ehtimal haqqında söylədiklərimiz düşüncə bədii mətnlərin yaranmasına xidmət etməlidir. Yəni nə qədər fərqli ifadə tərzi, üslub, forma yaratsa da, bədii mətnin düşüncə, məna qatına xidmət edib, onun bədiiliyinə xələl gətirməməlidir.

Ehtimal nəzəriyyəsinin başqa bir çox anlayışlarını və ayrı-ayrı məsələlərini şərh etməklə, onların bədii mətnlərdə bədii vasitə olaraq istifadəsi texnikasından söz açmaq mümkündür, lakin bunlar bu sahə barədə bir qədər dərin məlumatlara malik olmağ tələb edir. Belə olan halda, həmin məsələlər üzərində qurulmuş bədii mətnlər daha yaxşı anlaşılar və onlardan bədii həzz alınması mümkün olar. Oks halda, o mətnlər yalnız oxucunu düşünməyə vadar edər ki, əslində, bu da heç də səmərəsiz deyil.

Ehtimal nəzəriyyəsinin bəzi maraqlı məsələləri üzərində elmi-bəddi təfəkkürün sayəsində bədii mətnlər qurmaq və onları intellektual bədii mətnlərə yaxşı nümunə adlandırmaq olar. Hətta bunlardan bəzi poeziya nümunələrinə çəkinmədən "elmi şeir" də deyə bilərik.

İşi asanlaşdıraq deyə, məqsədimiz bu nəzəriyyə haqqında ümumi məlumat verməklə, bu elm sahəsinin əsas iki anlayışı - təsadüfi hadisə və ehtimal anlayışlarının intellektual bədii mətnlərlə doğmalığını aydınlaşdırmaqdan ibarət idi. Belə cəhdlər isə, hesab edirik ki, təkcə bu elm sahəsinin deyil, ümumiyyətlə, elm sahələrinin "düşüncə ədəbiyyatında" istifadə texnikası barədə müəyyən bilik və səriştə qazanmağa vasitə ola bilər.

Bir də, Ehtimal nəzəriyyəsinə bələd olmaqla, müşahidə oluna bilən hər hansı bir hadisənin baş verməsi haqqında bütün mümkün fərziyyələri (ehtimalları) bir araya gətirmək olar. Məsələn:

\section{$\ddot{U}$ ç forziyyo}

Bir neçə günlük yoxluğun

bir haqiqati anlatdl manə:

varlığın yox olması deyilmiş ölüm,

ölüm - yoxolmanın varlığ imiş.

Sonra üç farziyya galir ağlıma:

I farziyya: Mon yoxam.

Sən gözlayirsən. Qadın daha çox gözlantidi axı.

Çox gözlayirsan dönüşümü, lap çox. Anlayanda dönüşüm

hər dəfa dönüşüdü yoxluğumun, uzun-uzadı şəkillarima

baxmağa başlayırsan gözüyaşlı, siğal çəkirson bəzən

paltarlarıma. Gecəlar bağrına basıb yastığımı hönkürürsən, -

belo olur, adətən. Sonra yavaş-yavaş yoxluğumla danışmağa,

dərdlaşməyə alışırsan ... hər nəsə.

Omalli-başlı öyraşirsan Yoxluğuma.

II farziyya: Sən yoxsan,

daha doğrusu, varsan, yoxluq şəklindo.

Qayıdıram hardansa, farqi yox, işdən, gazintidon

va saira. Kişi da ki, daha çox qayıdışdı axı - bunu

deməmişəm, deyəsən. Açarı uzadıram qapının kilidinə ...

yoxluğun açır qapını, slimi uzadıram - yoxluğun yandırır işı̆̆ı. 


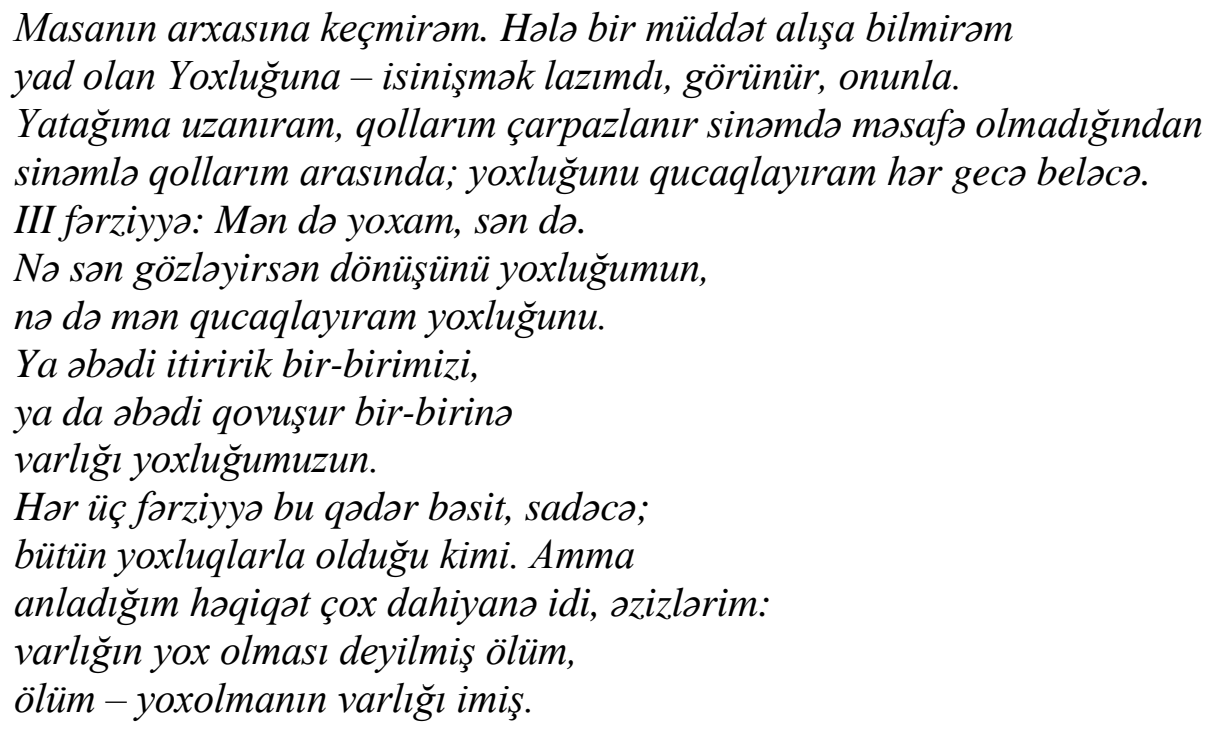

\section{Noticə}

Təbiət elmlərinin fəlsəfəsinin öyrənilməsi elmin fəlsəfəsi baxımından çağdaş dövrdə də öz aktuallığını saxlayır. Qeyri-səlis məntiq nəzəriyyəsi və Ehtimal nəzəriyyəsinin təbiət elmləri olaraq fərqli tərəfləri ilə yanaşı, oxşar cəhətlərinin də elmi-fəlsəfi düşüncə bucağından araşdırılması bu elm sahələrinə düzgün fəlsəfi yanaşmanı təmin edir. Eyni zamanda intellektual təmayüllü bədii yaradıcılıq nümunələrinin yaradılmasında elmi informasiyanın fəlsəfəsinin ədəbiyyat konteksində araşdırılması və bu fəlsəfənin bədii əsərlərin məna qatının zənginləşməsində istifadə konsepsiyasının əsaslandırılması bu istiqamətdə atılan zəruri addımlardan biridir. $\mathrm{Bu}$ araşdırmalar elmi informasiyaların fəlsəfəsinin ədəbiyyat konteksində məhz bu məqalədə təqdim olunan model əsasında nəzərdən keçirilməsi bir mərhələ rolunu oynaya bilər.

\section{İstifadə olunmuş ədəbiyyat}

1. "Süni intellekt, Qeyri-səlis məntiq və Fəlsəfə" elektron almanax. AMEA Fəlsəfə və Sosiologiya institutu. Bak1 2021.

2. Məmmədov Ә., Qurbanov F. Lütfi Zadənin Qeyri-səlis çoxluqlar nəzəriyyəsinin məntiqiqnoseoloji təhlili. BMM. "Metafizika" jurnalı 2019, cild 2, say1, sira 5.

3. Философия. Москва: Эксмо, 2019

4. Şopenhauer A. Müxtəlif predmetlər haqqında düşüncələr. Bak1: "Qanun” nəşriyyat1, 2018.

5. Скороход А.В. Элементы теории вероятностей и случайных процессов. Киев: «ВИЩА ШКОЛА» 1980

6. Şükürov Ә.S. Ehtimal nəzəriyyəsinin elementləri. Metodik vəsait. Bakı: Mütərcim, 1999.

7. Şükürlü Ә. Đdəbi suprematizm və dünyaya yeni baxış. Bakı: Vektor, 2019.

Göndərilib: 03.10.21 Qəbul edilib: 19.11.21 